\title{
Antioxidative properties and proximate analysis of spent coffee ground (SCG) extracted using ultrasonic-methanol assisted technique as a potential functional food ingredient
}

\author{
1,*Zainol, M.K., ${ }^{1}$ Mohd Subri, I., ${ }^{1}$ Zamri, A.I., ${ }^{1}$ Mohd Zin, Z., ${ }^{1}$ Fisal, A. and ${ }^{2}$ Mamat, H. \\ ${ }^{1}$ Faculty of Fisheries and Food Sciences, Universiti Malaysia Terengganu, 21030, Kuala Nerus, \\ Terengganu, Malaysia \\ ${ }^{2}$ Faculty of Food Science and Nutrition, Universiti Malaysia Sabah, 88400 Kota Kinabalu, Sabah, Malaysia
}

\begin{abstract}
Article history:
Received: 28 October 2019

Received in revised form: 13

December 2019

Accepted: 16 December 2019

Available Online: 1 January 2020
\end{abstract}

Keywords:

Ultrasonic methanol assisted extraction,

Antioxidative activities,

Spent coffee ground (SCG)

DOI:

https://doi.org/10.26656/fr.2017.4(3).358

\begin{abstract}
Spent coffee ground (SCG) produced in tons by restaurants and cafeterias and domestic consumers is a potentially good source of natural antioxidants because it contains substantial amounts of bioactive compounds. The purpose of this study was to identify the physicochemical and antioxidant properties of three different types of spent coffee ground (SCG), namely Robusta, Arabica and Liberica extracted using ultra-sonicmethanol assisted technique. DPPH, FTC, TBA, total phenolic content (TPC) and total flavonoid content (TFC) were used to measure the antioxidant properties. Robusta SCG exhibited the highest DPPH inhibition $41.63 \pm 0.04 \%)$, FTC $(60.42 \pm 0.03 \%)$ and TBA analysis $(73.09 \pm 0.08 \%)$. The total phenolic compounds in the samples varied widely ranging from $18.94 \pm 0.06$ to $26.23 \pm 0.86 \mathrm{mg} \mathrm{GAE} / \mathrm{g}$ sample, with Robusta SCG showing the highest value among the three, while Arabica SCG depicted the highest amount total flavonoid content $(47.62 \pm 0.05$ to $56.20 \pm 0.08)$. A strong correlation between antioxidant activity and total phenolic content were observed in this study. Compared to Arabica and Liberica SCGs expended, Robusta SCG demonstrated a stronger beneficial effect against lipid peroxidation. This study reveals that SCGs can be regarded as a new useful source of natural antioxidant with a view to increasing the use of antioxidant synthetics by using the ingredient of agro-industrial residues in food production especially ingredients for functional food.
\end{abstract}

\section{Introduction}

Coffee is one of the most popular beverages in the world, grown mainly in tropical and subtropical regions of Central and South America, Africa and South-East Asia, in temperature between 600 and $2500 \mathrm{~m}$ above sea level (Schenker et al., 2002). Coffee beans contain several classes of chemicals related to health, such as phenolic compounds, melanoidins, diterpenes, xanthines and vitamin precursors, especially antioxidants (AlDhabi et al., 2017). Coffee phenolics have attracted a lot of interest in recent years thanks to their powerful antioxidant and metal-chelating properties.

The coffee industry produces large quantities of residues and by-products, both liquid and solid (Nabais et al., 2008). One of the major residues of the coffee industry is the solid by-product known as spent coffee grounds (SCG). The resulting SCG may be considered as a source of potentially valuable bioactive compounds during the brewing process (Panusa et al., 2013). SCG is the residue obtained during the treatment of raw coffee powder with hot water or steam for instant coffee preparation with fine particle size, high humidity (ranging from 80 to $85 \%$ ), organic load and acidity. In addition, up to 50 per cent of the world's coffee supply is processed for soluble coffee preparation (Ramalakshmi et al., 2009). SCG is thus generated in large quantities, with an annual generation of 6 million tons worldwide (Tokimoto et al., 2005). Despite the large quantities that have been produced, few studies focus on their use in different and productive applications. Besides adding value to these recycled items, finding alternative ways to use them to reduce their environmental impact would be useful. The antioxidant properties are one of the beneficial factors that could be attributed by SCG.

Antioxidant is a material that protects living tissues from damage caused by free radicals. Free radicals are species formed during aerobic respiration due to the 
incomplete reduction of oxygen molecules and directly related to various diseases, such as cancer, cardiovascular, inflammatory and neurogenerative diseases, associated with oxidative stress (Adam et al., 2009). Plant extract showed different antioxidant activities depending on the different extraction methods, emphasizing the importance of choosing the correct method of antioxidant extraction (Hayouni et al., 2007). Classical or conventional extraction techniques are used to extract bioactive components from multiple plant materials on a small scale. Usually, these techniques are based on the extraction efficiency of the various solvents used for this purpose (Cowan, 1999). The major challenges of conventional extraction are longer extraction time, costly and high purity solvent requirement, massive solvent evaporation, low selectivity for extraction, and thermal decomposition of thermolabile compounds (Ignat et al., 2011). This research was therefore aimed at evaluating the properties of antioxidants and chemical compositions extracted in the SCG using technique supported by ultrasonic methanol as the possibility of using agro-industrial waste as a high-end quality product.

\section{Materials and methods}

The coffee ground of three different types; Arabica, Robusta and Liberica, were obtained from Kilang Kopi FAMA Banting (Selangor, Malaysia) in July 2017. The coffee brews were prepared as described by Bravo et al. (2013) with some modifications. Coffee beans are ground with a grinder for $1 \mathrm{~min}$ at $10 \mathrm{~s}$ intervals. The brew was prepared using a French Press coffee maker (Uppheta, India) with $40 \mathrm{~g}$ ground roasted coffee, extracted from the plunger brewer by adding $500 \mathrm{~mL}$ of water at $98^{\circ} \mathrm{C}$. The coffee was brewed for $5 \mathrm{~min}$ before the plunger was slowly pushed down. Then the SCGs were collected, drained and stored at $-18^{\circ} \mathrm{C}$.

\subsection{Ultrasonic-methanol assisted extraction}

The extraction assisted by ultrasonic methanol was performed with modification as mention by Zainol et al. (2018). In addition to $100 \mathrm{~mL}$ of $60 \% \mathrm{v} / \mathrm{v}$ methanol, 10 $\mathrm{mg}$ of SCG were extracted in an ultrasonic bath (JEIO Tech, Korea) at $50 \mathrm{kHz}, 400 \mathrm{~W}$ at $40^{\circ} \mathrm{C}$ for $6 \mathrm{hrs}$. The samples were collected, filtered and concentrated in a rotary evaporator (BUCHI Rotavapor R-215, Switzerland). The samples then were stored in amber bottles at $-18^{\circ} \mathrm{C}$.

\subsection{Proximate analysis}

Proximate analysis was conducted to determine the percentage of moisture, ash, crude protein, crude fat, and crude fibre, according to the Association of Official
Analytical Chemists' procedure (AOAC, 2005). The carbohydrates were determined by difference (Nitisewojo, 1995).

\subsection{Identification of functional groups}

The sampling technique used was transmission (4000-450 wavenumber), 32 scans modified from Durga Maha Lakshmi et al. (2014). The sample and KBr (FTIR grade) were made into pallet in the ratio of $10 \mathrm{mg}$ : 500 mg using the pallet maker. The pallet was inserted into a holder within the FTIR and spectrum was obtained.

\subsection{Determination of antioxidative properties}

\subsubsection{2,2-diphenyl-2-picrylhydrazyl}

$(D P P H)$

Radical Scavenging Assay

The free radical scavenging activity of SCG extracts was evaluated according to the method reported in Gyamfi et al. (1999). Four mg of the extract in methanol, yielding $4 \mathrm{mg} / 1 \mathrm{~mL}$ respectively in each reaction was mixed with $3 \mathrm{~mL}$ of $0.1 \mathrm{mM}$ DPPH in methanol solution. Methanol $(1 \mathrm{~mL})$ was used as control of the experiment. After 60 mins of incubation at room temperature, the reduction of the DPPH free radical was measured by reading the absorbance at $517 \mathrm{~nm}$.

\subsubsection{Ferric thiocyanate (FTC) method}

The standard method as described by Kikuzaki and Nakatani (1993) and Zainol et al. (2003) was used with slight modifications. A mixture of $4.0 \mathrm{mg}$ extract in 4 $\mathrm{mL}$ absolute ethanol, $4.1 \mathrm{~mL}$ of $2.5 \%$ linolenic acid in absolute ethanol, $8.0 \mathrm{~mL}$ of $0.05 \mathrm{M}$ phosphate buffer $(\mathrm{pH}$ 7.0 ) and $3.9 \mathrm{~mL}$ of water were placed in a test tube and then placed in the water bath shaker in the dark at $40^{\circ} \mathrm{C}$ for $24 \mathrm{hrs}$. $0.1 \mathrm{~mL}$ of this solution was added with 9.7 $\mathrm{mL}$ of $75 \%$ ethanol and $0.1 \mathrm{~mL}$ of $30 \%$ ammonium thiocyanate. Precisely 3 mins after adding $0.1 \mathrm{~mL}$ of 0.02 $\mathrm{M}$ ferrous chloride in 3.5 per cent $\mathrm{HCl}$ to the reaction mixture, the absorption of red colour will be measured at $500 \mathrm{~nm}$ every $24 \mathrm{hrs}$ until the day after the peak control absorption has been reached.

\subsubsection{Thiorbarbituric acid (TBA) method}

The test was conducted according to the method of Zainol et al. (2003). To $2.0 \mathrm{~mL}$ of the sample solution, $1.0 \mathrm{~mL}$ of $20 \%$ aqueous trichloroacetic acid (TCA) and $2.0 \mathrm{~mL}$ of $0.67 \%$ aqueous thiobarbituric acid (TBA) solution were added. The final sample concentration was $0.02 \% \mathrm{w} / \mathrm{v}$. The mixture was placed in a boiling water bath for 10 mins. After cooling to $25^{\circ} \mathrm{C}$, it was then centrifuged at $3000 \mathrm{rpm}$ for $20 \mathrm{mins}$. The absorbance of the supernatant was measured at $531 \mathrm{~nm}$. Antioxidant activity was recorded based on the absorbance of the final day of the FTC assay. 


\subsubsection{Determination of total phenolic content (TPC)}

Total phenolic content in spent ground coffee was determined by using the Folin-Ciocalteu reagent according to the colourimetric method, with modifications, as described by $\mathrm{Ng}$ et al. (2020). Approximately $4 \mathrm{~mL}$ of extract was mixed with $2 \mathrm{~mL}$ of sodium carbonate solution at $7.5 \%(\mathrm{w} / \mathrm{v})$ and $7.5 \mathrm{~mL}$ of $10 \%$ Folin-Ciocalteu reagent. The mixtures were let to stand at room temperature for $3 \mathrm{~h}$ and measured at 760 $\mathrm{nm}$. The total phenolic content was expressed as milligram gallic acid equivalent $(\mathrm{GAE} / 100 \mathrm{~mL})$ per dry weight material.

\subsubsection{Determination of total flavonoid content (TFC)}

Flavonoid content was determined using the colourimetric assay as described by Chang et al. (2002) with some modifications. A volume of $4 \mathrm{mg}$ of the sample was added with $1.5 \mathrm{~mL}$ methanol, $0.1 \mathrm{~mL}$ of aluminium chloride at $10 \%(\mathrm{w} / \mathrm{v}), 0.1 \mathrm{~mL}$ of potassium acetate $(1 \mathrm{M})$, and $2.8 \mathrm{~mL}$ of distilled water. The absorbance of the mixtures was measured at $415 \mathrm{~nm}$ against a blank of distilled water. The total flavonoid content was expressed as quercetin equivalents $(\mathrm{QE} / 100$ $\mathrm{mL})$.

\subsection{Statistical analysis}

The data was collected and analysed using one-way variance (ANOVA) with multiple comparisons and the significant difference $(p<0.05)$ data were further analysed using Fisher's test at 95\% confidence intervals. The data were analysed using Minitab 14 software and all data obtained were presented at mean \pm standard deviation (Wasnin et al., 2012).

\section{Results and discussion}

\subsection{Proximate analysis}

Table 1 shows that Liberica SCG contained the highest carbohydrates content which $(8.91 \pm 0.02 \%)$, compared to Robusta and Arabica which are $6.76 \pm 0.13 \%$ and $6.22 \pm 0.04 \%$, respectively. Meanwhile, for fat content, Liberica SCG depicted the highest fat compared to Arabica and Robusta SCGs. The analysis found a different value $(p<0.05)$ between all three spent coffee, where Liberica SCG displayed a percentage of $2.78 \pm 0.07 \%$ while Robusta SCG $(1.67 \pm 0.03 \%)$ spent coffee and Arabica SCG (1.38 $\pm 0.03 \%)$ had a lower fat content. These differences can also be due to the conditions used for instant coffee preparation and the variety of coffee beans used (Mussatto et al., 2011). Protein content shows significance results $(\mathrm{p}<0.05)$ between Arabica, Robusta and Liberica SCGs. Liberica SCG was found to have the highest protein content with $7.20 \pm 0.01$. Wasserman (1992), stated that the protein content of Arabica and Robusta differs significantly, even though the total amino acid composition is similar. Arya and Rao (2007) stated that roasted coffee contains on average $3.1 \%(\mathrm{w} / \mathrm{w})$ protein. During the instant coffee preparation process, many of the other grain components are extracted and, as a result, the non-extracted components are concentrated in the residual solid material. Therefore, the protein content is higher in SCG than in the coffee grains. It must be emphasized that as the protein content in SCG was calculated from the total nitrogen content of the samples, it may have been overestimated due to the presence of other nitrogencontaining substances such as caffeine, trigonelline, free amines and amino acids (Delgado et al., 2008).

\subsection{Identification of functional groups}

Typical FTIR spectra obtained for SCGs are shown in Figure $1(\mathrm{a}, \mathrm{b}, \mathrm{c})$. The SCG spectrums showed two sharp bands that can be viewed in the $2800-3000 \mathrm{~cm}^{-1}$ range have been reported for all three SCG samples, are attributed to $\mathrm{C}-\mathrm{H}$ stretching vibration. These bands have been previously reported in spectra of roasted Arabica and Robusta coffee samples (Kemsley et al., 1995) and roasted coffee husks (Reis et al. 2013). Moreover, studies of FTIR analysis from caffeinated beverages such as tea, coffee, and soft drinks have reported peaks at this same region $\left(2,882\right.$ and $\left.2,829 \mathrm{~cm}^{-1}\right)$, which are related to the asymmetric stretching of $\mathrm{C}-\mathrm{H}$ bonds of methyl $(-\mathrm{CH} 3)$ group in the caffeine molecule (Paradkar and Irudayaraj, 2002). Atmospheric $\mathrm{CO}_{2}$ bands are present at range between 2300-2200 $\mathrm{cm}^{-1}$ (antisymmetric $\mathrm{C}=\mathrm{O}$ stretch), however, it was not detected in spent Arabica. The band between 1,700 and $1,600 \mathrm{~cm}^{-1}$ is highly

Table 1. Proximate analysis of different types of SCG extracted using Ultrasonic-methanol assisted technique

\begin{tabular}{lccc}
\hline Proximate Analysis & Arabica SCG & Robusta SCG & Liberica SCG \\
\hline Moisture Content & $66.51 \pm 0.53^{\mathrm{a}}$ & $65.55 \pm 0.48^{\mathrm{a}}$ & $61.83 \pm 0.08^{\mathrm{b}}$ \\
Ash & $0.55 \pm 0.05^{\mathrm{a}}$ & $0.64 \pm 0.02^{\mathrm{a}}$ & $0.51 \pm 0.02^{\mathrm{a}}$ \\
Protein & $5.15 \pm 0.21^{\mathrm{c}}$ & $6.55 \pm 0.07^{\mathrm{b}}$ & $7.20 \pm 0.01^{\mathrm{a}}$ \\
Fat & $1.38 \pm 0.03^{\mathrm{c}}$ & $1.67 \pm 0.03^{\mathrm{b}}$ & $2.79 \pm 0.07^{\mathrm{a}}$ \\
Fibre & $19.82 \pm 0.22^{\mathrm{c}}$ & $19.58 \pm 0.18^{\mathrm{b}}$ & $19.13 \pm 0.16^{\mathrm{a}}$ \\
Carbohydrates & $6.22 \pm 0.04^{\mathrm{a}}$ & $6.76 \pm 0.13^{\mathrm{a}}$ & $8.91 \pm 0.02^{\mathrm{a}}$ \\
\hline
\end{tabular}

Values represent mean \pm standard deviation. Mean with the same superscript letter are not significantly different $(\mathrm{P}<0.05)$ between samples within rows in the table. 


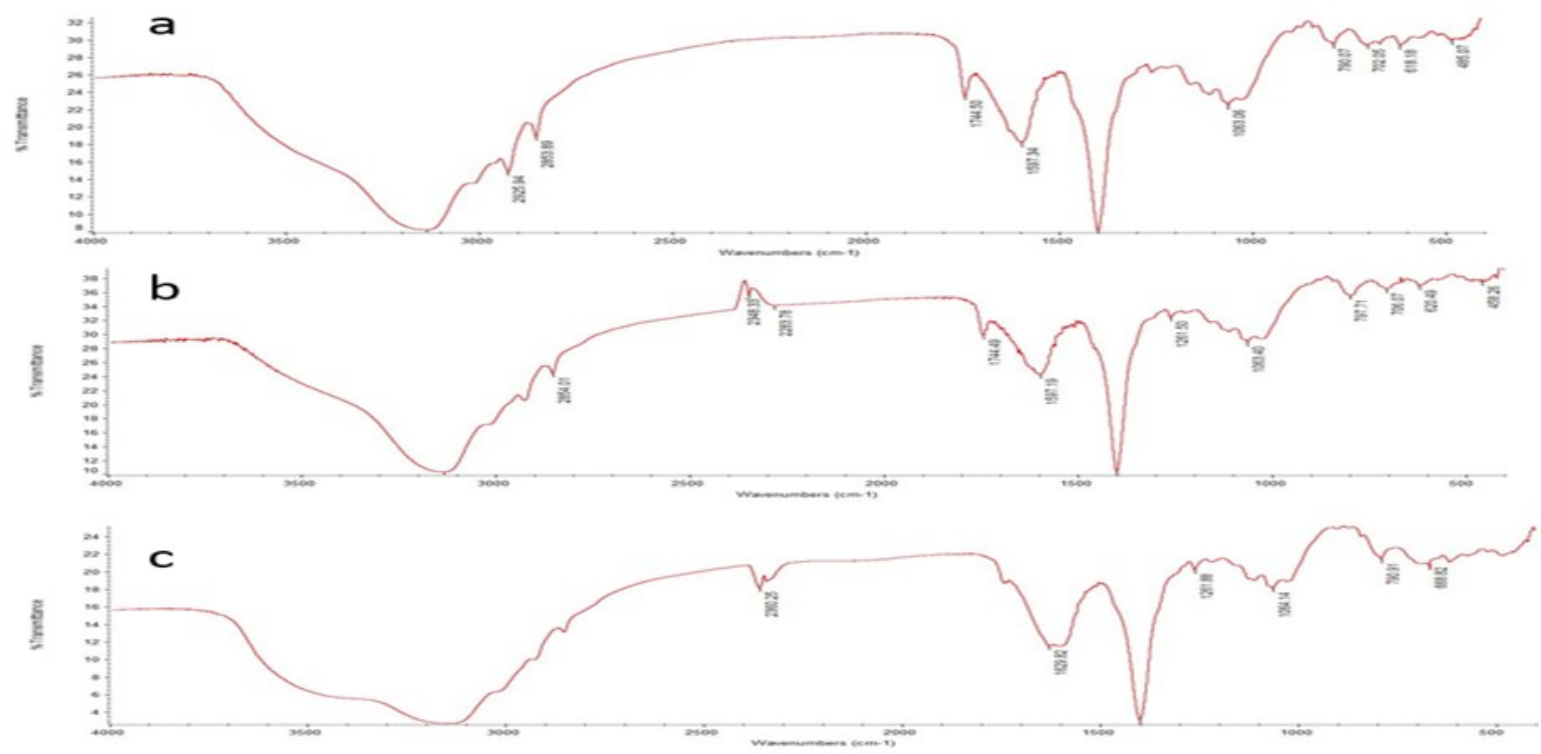

Figure 1. Absorbance spectrums recorded of (a) Robusta SCG (b) Arabica SCG (c) Liberica SCG extracted using ultrasonicmethanol assisted technique.

associated with chlorogenic acids and caffeine (Ribeiro et al., 2010), which can be seen on all three SCG spectra. However, it showed that Arabica SCG spectrum has monosubstituted aromatic hydrocarbons at the same range. The broad band between 1,063 and $702 \mathrm{~cm}^{-1}$ results from the stretching vibration of $\mathrm{C}-\mathrm{O}$ in $\mathrm{C}-\mathrm{O}-\mathrm{H}$ bonds such as glycosidic bonds and are related to galactomannans polysaccharide' sugars (Figueiró et al., 2004). In the range $1000-1001 \mathrm{~cm}^{-1}$ found that there is aliphatic primary amines for each SCG sample meanwhile the sharp peak at $1200-1500 \mathrm{~cm}^{-1}$ range, it was found that inorganic amines also at every sample. The bands in the $700-1000 \mathrm{~cm}^{-1}$ range for each spent Arabica, Robusta and Liberica SCGs, which indicates the presence of functional group belonging to inorganic nitrates and aliphatic primary amines.

\subsection{Antioxidant activities}

\subsubsection{DPPH radical scavenging assay}

Figure 2(A), showed that Robusta (41.63 $\pm 0.06 \%)$ shows the highest values for DPPH inhibition, and followed by Arabica $(32.85 \pm 0.01 \%)$ and Liberica $(29.95 \pm 0.04 \%)$. All three SCG extracts showed significantly $(\mathrm{p}<0.05)$ lower DPPH radical scavenging activity than the standards used, BHT, vitamin C and vitamin $\mathrm{E}$ which have shown $90.26 \pm 0.01 \%$, $92.78 \pm 0.04 \%$ and $92.57 \pm 0.03 \%$ of $\mathrm{DPPH}$ radical scavenging activity, respectively. This analysis is in agreement with findings by Murthy et al. (2012) which obtained higher DPPH radical scavenging activity on standards than the coffee samples, albeit in different amount. This is probably due to the BHT, vitamin $\mathrm{C}$ and vitamin $\mathrm{E}$ having the nature of being the established antioxidants, thus having higher ability to donate electron than the spent coffee samples. Plus, according to the previous study, although $C$. liberica is less used commercially, the antioxidant effect of its green seeds is comparable to that of $C$. arabica and C. robusta (Patay et al., 2016).

\subsubsection{Ferric thiocyanate (FTC) method}

Figure 2(B) exhibits the results from FTC method of different SCG extract on the $6^{\text {th }}$ day of incubation. The results depicted that all samples, Arabica, Robusta, Liberica SCGs exhibited slightly stronger antioxidant activities $(p<0.05)$ than that of ascorbic acid. However, the SCG extracts samples were found to be significantly lower percentage of inhibition $(p<0.05)$ than that of BHT. Robusta SCG extract showed the best lipid peroxide inhibition followed by Arabica spent and Robusta SCG extract being the lowest. This finding is in agreement with the finding of Emami et al. (2013) who found that the inhibition increases from ascorbic acid to samples, and standard BHT having the highest inhibition.

\subsubsection{Thiobarbituric acid (TBA) method}

Figure 2(C) shows that Robusta SCG exhibits significantly higher $(\mathrm{p}<0.05)$ antioxidant activity $(73.09 \pm 0.08 \%)$ to that of Arabica SCG $(51.34 \pm 0.30 \%)$ and Liberica SCG $(38.19 \pm 0.05 \%)$. It also showed that BHT $(90.9 \pm 0.26 \%)$ has a large significance difference $(p<0.05)$ compared to ascorbic acid $(31.54 \pm 0.05 \%)$. As FTC and TBA analysis are both determined the antioxidant activity towards lipid peroxidation, when comparing both results, it can be observed that spent Robusta exhibited higher antioxidant activity than that of Arabica and Robusta SCGs. Thus it can be assumed that Robusta SCG has more effect against lipid oxidation compared to the other two. Malik et al. (2017) reported that the higher antioxidant activity found from the FTC 

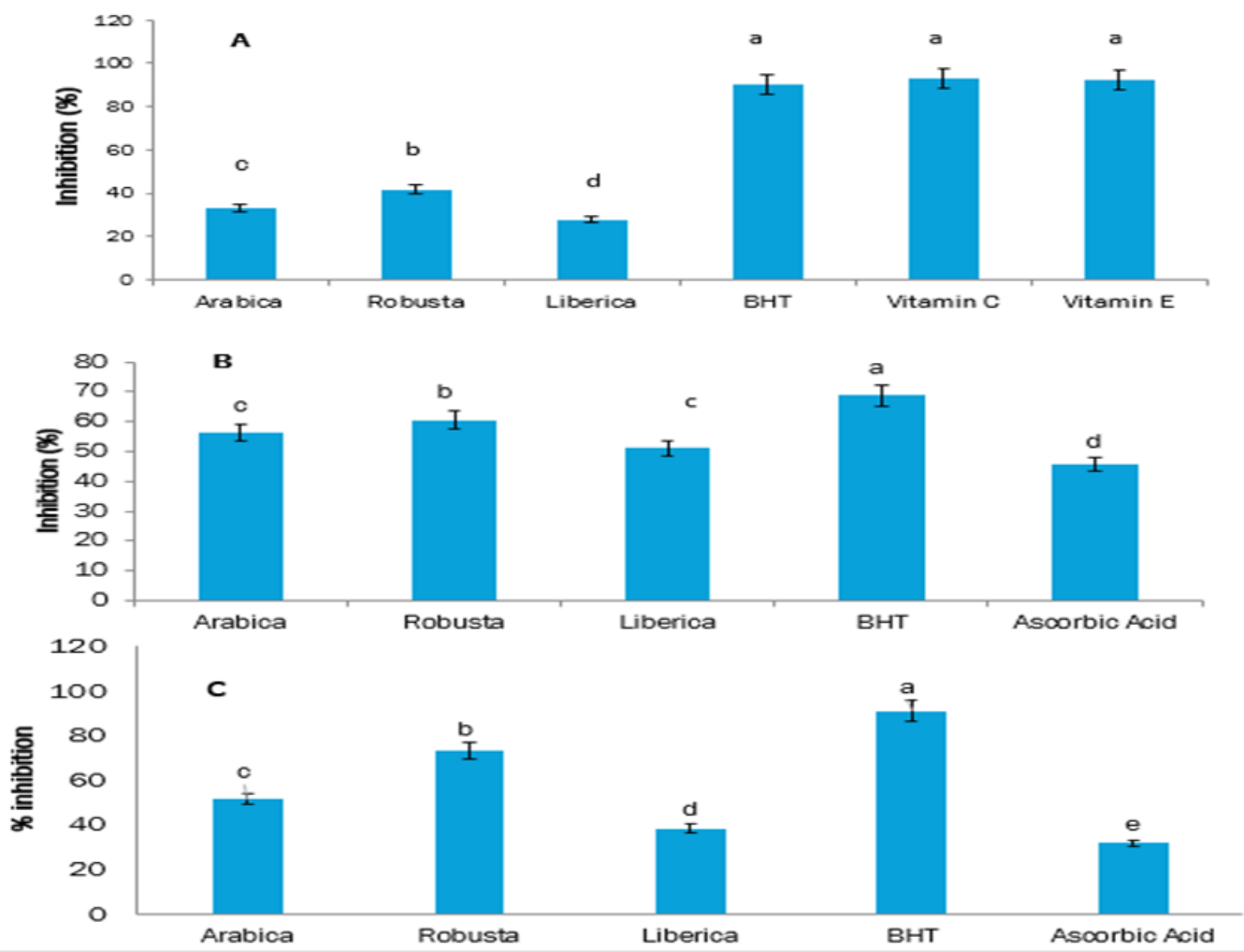

Figure 2. (A) Antioxidant activities measured using DPPH method of different SCGs. (B) Antioxidant activities measured using FTC method of different SCG extract on the 6th day of incubation period. (C) Antioxidant activities of different SCGs measured using TBA method. Values are expressed as mean \pm standard deviation. Mean with the same letter $(a, b, c)$ are not significantly different $(\mathrm{p}<0.05)$ between samples within rows in the table.

method indicated that the amount of peroxide in the initial stage of lipid peroxidation was greater than the amount of peroxide in the secondary stage.

\subsubsection{Total phenolic content}

Figure 3(A) depicts that all of the SCG samples contained an appreciable amount of phenolic compounds. The data shows that total phenolic compounds in the samples varied widely ranged from $18.94 \pm 0.06$ to $26.23 \pm 0.86 \mathrm{mg} \mathrm{GAE} / \mathrm{g}$ sample, with Robusta being the highest value among the three. This is consistent with the findings of Buddryn and Nebesny (2008) and Ramalakshmi et al. (2009) that Robusta coffee is usually of higher phenol content, be it coffee beans in spent coffee. These values are also consistent with those of the few published SCG studies (Bravo et al., 2013). The high amount of total phenolic is explained by Rabeta and An Nabil (2013) which indicated that phenolic compounds are water-soluble natural antioxidants, which are normally an aromatic ring containing one or more hydroxyl substitutes, which are abundant in plant-based materials. In addition, they are higher than those found for some other agro-industrial side products. Several compounds may contribute to the amount of TPC in the plant extract, mainly phenolic acid, flavonoids and anthocyanins (Naczk and Shahidi, 2004).

\subsubsection{Determination of total flavonoid content}

Figure 3(B) shows that Arabica SCG exhibited the highest TFC, followed by Robusta SCG and Liberica SCG. Flavonoids are a large group of ubiquitous molecules and possess antioxidant activities. SCG extracts with high radical scavenging activity also showed high flavonoid content. A similar phenomenon wherein the case of DPPH radical scavenging with both TPC and TFC, a non-significant correlation was found (Ghasemi et al., 2009). It is known that only flavonoids with a certain structure and, in particular, hydroxyl position in the molecule can act as a donation proton and show radical scavenging activity (Hou et al., 2003). It is therefore assumed that the concentration of flavonoids was not directly related to the antioxidant capacity of the sample extract as not all flavonoids could exhibit equivalent antioxidant strength. In addition, plant extracts are very complex mixtures of many different compounds with distinct activities (Mensor et al., 2001).

\subsubsection{Correlations between antioxidant activity with $T P C$ and TFC}

Figure $4(\mathrm{a}, \mathrm{b}, \mathrm{c})$ show the correlation between antioxidative activities and total phenolic compounds in SCG. All data showed strong linear regression of antioxidative activities and total phenolic content in studied samples as indicated by high $\mathrm{r}^{2}$ at ranging from +0.79 to 0.98 , suggesting that phenolic compounds are 

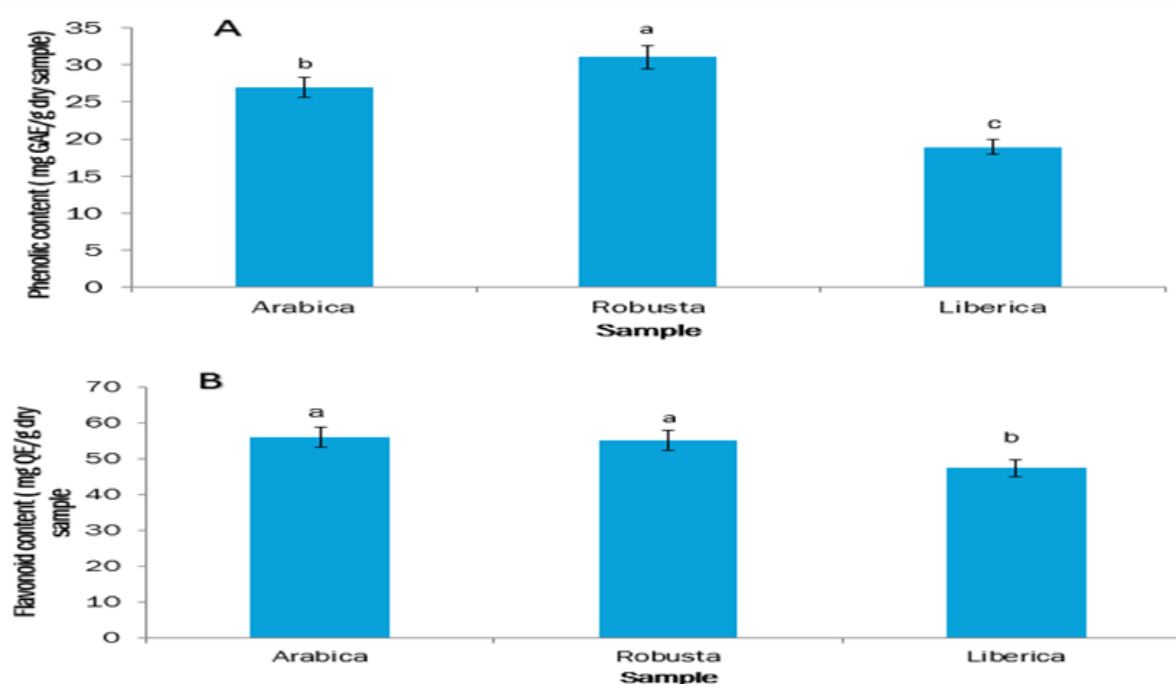

Figure 3. (A) Total Phenolic Content (mg GAE/g sample) of different SCGs. (B) Total Flavonoid Content (mg QE/g sample) of different SCG. Values represent mean \pm standard deviation. Mean with the same letter $(a, b, c)$ are not significantly different $(\mathrm{P}<0.05)$ between samples.
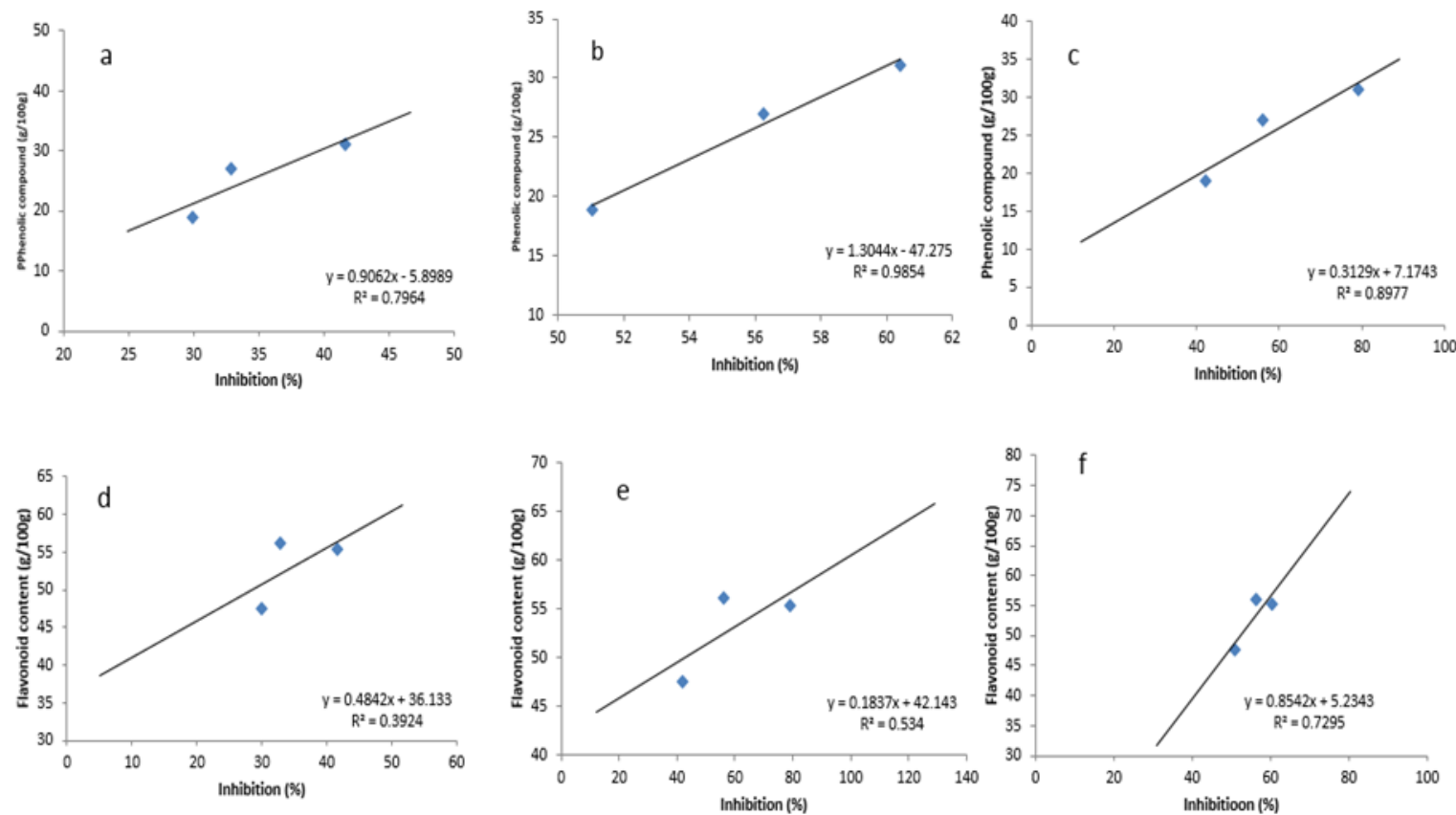

Figure 4. Regression of total phenolic content in SCG against antioxidant activity by (a) DPPH, (b) FTC, and (c) TBA, and Regression of total flavonoid content against antioxidant activity in SCG by (d) DPPH, (e) FTC and (f) TBA

greatly contributing to the antioxidative activities of SCG. A similar finding was reported by Zainol et al. 2003) who suggested that phenolic compounds are the ones that responsible for the antioxidative activity of Centella asiatica. Thus, the therapeutic properties of SCG extracts may possibly be attributed to the phenolic compounds present. Figure 4 (d, e, f) show the correlation between antioxidative activities and total flavonoid content in SCG. The data shows the weak but positive correlation between antioxidative activities and total flavonoid content with $\mathrm{r}^{2}$ ranging from +0.39 to 0.73 , suggesting that TFC is not a very good contributor to antioxidative activities in SCG especially by the DPPH radical. This finding is in line with Abdel-Naim et al. (2009) which observed that the degree of linear regression was slightly low in case of percentage DPPH scavenging activity than the other analyses. According to Chang et al. (2002), flavonoids with 3'-OH, 5'-OH and ortho-dihyroxyl group at ring $\mathrm{A}$ and $\mathrm{B}$ (flavones, flavanols) will complex well with aluminium chloride while the others (flavanones and isoflavones) will react well with 2,4- dinitrophenylhydrazine colourimetric method. In addition, the weak correlations indicated that antioxidant activity not only contributed by flavonoids but there are possible synergistic or competitive antioxidant action among the phenolics like $\beta$-carotene, and anthocyanin (Imeh and Kokhar, 2002).

\section{Conclusion}

Ultrasonic-methanol assisted extraction, have shown 
a good capability to extract bioactive compounds from SCGs producing extracts with superior antioxidant capabilities to most of those reported earlier. This study reveals SCG as a valuable new source of natural antioxidants, with a view to reducing the use of synthetic antioxidants by the use of agro-industrial residues in food production especially ingredients for functional food.

\section{Conflict of Interest}

The authors declare that there is no conflict of interest.

\section{Acknowledgments}

This research was supported by Universiti Malaysia Terengganu. The authors would like to thank the UMT's central lab and Faculty of Fisheries and Food Science for the facilities provided to conduct the study.

\section{References}

Adam, M., Dobiáś, P., Eisner, A. and Ventura, K. (2009). Extraction of antioxidants from plants using ultrasonic methods and their antioxidant capacity. Journal of Separation Science, 32(2), 288-294. https://doi.org/10.1002/jssc.200800543

Abdel-Naim, A.B., El-Beshbishy, H.A. and Mohamadin, A.M. (2009). In vitro evaluation of the antioxidant activities of Grape seed (Vitis vinifera) extract, Blackseed (Nigella sativa) extract and Curcumin. Journal of Taibah University Medical Sciences, 1(4), 23-35. https://doi.org/10.1016/S1658-3612(09)70078 $-2$

Al-Dhabi, N.A., Ponmurugana, K. and Jeganathan, P.M. (2017). Development and validation of ultrasoundassisted solid-liquid extraction of phenolic compounds from waste spent coffee grounds. Ultrasonics Sonochemistry, 34, 206-213. https:// doi.org/10.1016/j.ultsonch.2016.05.005

AOAC. (2005). Official Methods of Analysis. Washington, DC: Association of Official Analytical Chemists.

Arya, M. and Rao, L.J.M. (2007). An impression of coffee carbohydrates. Critical Reviews in Food Science and Nutrition, 47(1), 51-67. https:// doi.org/10.1080/10408390600550315

Bravo, J., Monente, C., Juániz, I., De Peña, M. and Cid, C. (2013). Influence of extraction process on antioxidant capacity of spent coffee. Food Research International, 50(2), 610-616. https:// doi.org/10.1016/j.foodres.2011.04.026

Chang, C.-C., Yang, M.-H., Wen, H.-M. and Chern, J.-C. (2002). Estimation of total flavonoid content in propolis by two complementary colourimetric methods. Journal of Food and Drug Analysis, 10(3), 178-182.

Cowan, M.M. (1999). Plant products as antimicrobial agents. Clinical Microbiology Reviews, 12, 564-582. https://doi.org/10.1128/CMR.12.4.564

Delgado, P.A, Vignoli, J.A, Siika-Aho, M. and Franco, T.T. (2008). Sediments in coffee extracts: Composition and control by enzymatic hydrolysis. Food Chemistry, 110(1), 168-176. https:// doi.org/10.1016/j.foodchem.2008.01.029

Durga Maha Lakshmi, C.H.N., Prasad, R.B.D, Madhavi, T. and Sushma, N.J. (2014). Identification of bioactive compounds by FTIR analysis and in vitro antioxidant activity of Clitoria ternatea leaf and flower extracts. Indo American Journal of Pharmaceutical Research, 4(9), 3894-3903.

Emami, S.A., Shahani, A. and Khayyat, M.H. (2013). Antioxidant Activity of Leaves and Fruits of Cultivated Conifers in Iran. Jundishapur Journal of Natural Pharmaceutical Products, 8(3), 113-117. https://doi.org/10.17795/jjnpp-9670

Figueiró, S.D., Góes, J.C., Moreira, R.A. and Sombra, A.S.B. (2004). On the physico-chemical and dielectric properties of glutaraldehyde crosslinked galactomannan-collagen films. Carbohydrate Polymers, 56(3), 313-320. https://doi.org/10.1016/ j.carbpol.2004.01.011

Ghasemi, K., Ghasemi, Y. and Ebrahimzadeh, M.A. (2009). Antioxidant activity, phenol and flavonoid contents of 13 citrus species peels and tissues. Pakistan Journal of Pharmaceutical Sciences, 22(3), 277-281.

Gyamfi, M.A., Yonamine, M. and Aniya, Y. (1999). Free-radical scavenging action of medicinal herbs from Ghana: Thonningia sanguinea on experimentally-induced liver injuries. General Pharmacology: Vascular System, 32(6), 661-667. https://doi.org/10.1016/S0306-3623(98)00238-9

Hayouni, E., Abedrabba, M., Bouix, M. and Hamdi, M. (2007) The effect of solvents and extraction method on the phenolic compounds' contents and biological activities in vitro of Tunisian Quercus coccifera L. and Juniperus phoenicea L. fruit extract. Food Chemistry, 105(3), 1126-1134. https:// doi.org/10.1016/j.foodchem.2007.02.010

Hou, W.C., Lin, R.D., Cheng, K T., Hung, Y.T., Cho, C.H., Chen, C.H. and Lee, M.H. (2003). Free radical -scavenging activity of Taiwanese native plants. Phytomedicine, 10(2-3), 170-175. https:// doi.org/10.1078/094471103321659898

Ignat, I., Volf, I. and Popa, V. (2011). A critical review 
of methods for characterisation of polyphenolic compounds in fruits and vegetables. Food Chemistry, 126(4), 1821-1835. https:// doi.org/10.1016/j.foodchem.2010.12.026

Imeh, U. and Khokhar, S. (2002). Distribution of conjugated and free phenols in fruits: antioxidant activity and cultivar variations. Journal of Agricultural and Food Chemistry, 50(22), 63016306. https://doi.org/10.1021/jf020342j

Kemsley, E.K., Ruault, S. and Wilson, R.H. (1995). Discrimination between Coffea arabica and Coffea canephora variant robusta beans using infrared spectroscopy. Food Chemistry, 54(3), 321-326. https://doi.org/10.1016/0308-8146(95)00030-M

Kikuzaki, H. and Nakatani, N. (1993). Antioxidant effects of some ginger constituents. Journal of Food Science, 58(6), 1407-1410. https://doi.org/10.1111/ j.1365-2621.1993.tb06194.x

Malik, N.H., Mohd-Zin, Z, Abd Razak, S.B, Ibrahim, K. and Zainol, M.K. (2017). Antioxidative activities and flavonoids contents in leaves of selected Mangrove species in Setiu Wetlands extracted using different solvents. Journal of Sustainability Science and Management, 3, 14-22.

Mensor, L.L., Menezes, F.S., Leitão, G.G., Reis, A.S., Santos, T.C.D., Coube, C.S. and Leitão, S.G. (2001). Screening of Brazilian plant extracts for antioxidant activity by the use of DPPH free radical method. Phytotherapy Research, 15(2), 127-130. https:// doi.org/10.1002/ptr.687

Murthy, P.S., Manjunatha, M.R., Sulochannama, G. and Naidu, M.M. (2012). Extraction, characterization and bioactivity of coffee anthocyanins. European Journal of Biological Science, 4(1), 13-19.

Mussatto, S., Ballesteros, L., Martins, S. and Teixeira, J. (2011). Extraction of antioxidant phenolic compounds from spent coffee grounds. Separation and Purification Technology, 83, 173-179. https:// doi.org/10.1016/j.seppur.2011.09.036

Nabais, J.M.V., Nunes, P., Carrott, P.J.M., Carrott, M.R., García, A.M. and Díez, M.A.D. (2008). Production of activated carbons from coffee endocarp by $\mathrm{CO}_{2}$ and steam activation. Fuel Processing Technology, 89(3), 262-268.

https://doi.org/10.1016/ j.fuproc.2007.11.030

Naczk, M. and Shahidi, F. (2004). Extraction and analysis of phenolics in food. Journal of Chromatography A, 1054(1-2), 95-111. https:// doi.org/10.1016/S0021-9673(04)01409-8

Ng, K.S., Mohd Zin, Z., Mohd Maidin, N. and Zainol, M.K. (2020). The ramification of fermentation time on antioxidant properties of Napier grass herbal tea by black tea processing method. Food Research, 4 (2), 349 - 357. https://doi.org/10.26656/fr.2017.4 (2). 265

Nitisewojo, P. (1995). Prinsip analisis makanan. Bangi: Penerbit Universiti Kebangsaan Malaysia.

Panusa, A., Zuorro, A., Lavecchia, R., Marrosu, G. and Petrucci, R. (2013). Recovery of natural antioxidants from spent coffee ground. Journal of Agricultural and Food Chemistry, 61(17), 4162-4168. https:// doi.org/10.1021/jf4005719

Paradkar, M.M. and Irudayaraj, J. (2002). A rapid FTIR spectroscopic method for estimation of caffeine in soft drinks and total methylxanthines in tea and coffee. Journal of Food Science, 67(7), 2507-2511. https://doi.org/10.1111/j.1365-2621.2002.tb08767.x

Patay, É.B., Sali, N., Kőszegi, T., Csepregi, R., Balázs, V.L., Németh, T.S. and Papp, N. (2016). Antioxidant potential, tannin and polyphenol contents of seed and pericarp of three Coffea species. Asian Pacific Journal of Tropical Medicine, 9(4), 366-371. https://doi.org/10.1016/j.apjtm.2016.03.014

Rabeta, M.S. and An Nabil, Z. (2013). Total phenolic compounds and scavenging activity in Clitoria ternatea and Vitex negundo linn. International Food Research Journal, 20(1), 495-500.

Ramalakshmi, K., Rao, L., Takano-Ishikawa, Y. and Goto, M. (2009). Bioactivities of low-grade green coffee and spent coffee in different in vitro model systems. Food Chemistry, 115(1), 79-85. https:// doi.org/10.1016/j.foodchem.2008.11.063

Reis, N., Franca, A.S. and Oliveira, L.S. (2013). Performance of diffuse reflectance infrared Fourier transform spectroscopy and chemometrics for detection of multiple adulterants in roasted and ground coffee. LWT-Food Science and Technology, 2(53), 395-401. https://doi.org/10.1016/ j.lwt.2013.04.008

Ribeiro, J.S., Salva, T.J. and Ferreira, M.M.C. (2010). Chemometric studies for quality control of processed Brazilian coffees using drifts. Journal of Food Quality, 33(2), 212-227. https://doi.org/10.1111/ j.1745-4557.2010.00309.x

Schenker, S., Heinemann, C., Huber, M., Pompizzi, R., Perren, R. and Escher, R. (2002). Impact of roasting conditions on the formation of aroma compounds in Coffee beans. Journal of Food Science 67(1), 60-66. https://doi.org/10.1111/j.1365-2621.2002.tb11359.x

Tokimoto, T., Kawasaki, N., Nakamura, T., Akutagawa, J. and Tanada, S. (2005). Removal of lead ions in drinking water by coffee grounds as vegetable biomass. Journal of Colloid and Interface Science, 281(1), 56-61. https://doi.org/10.1016/ 
j.jcis.2004.08.083

Wasnin, R.M., Karim, M.S.A. and Ghazali, H.M. (2012). Effect of temperature-controlled fermentation on physico-chemical properties and lactic acid bacterial count of durian (Durio zibethinus Murr.) pulp. Journal of Food Science and Technology, 51(11), 2977-2989. https://doi.org/10.1007/s13197-0120869-7

Wasserman, G. (1992). Coffee. In Kirk-Othmer (Ed.). Kirk-Othmer Encyclopedia of Chemical Technology. Vol. $6,4^{\text {th }}$ ed. USA: John Wiley and Sons, Inc.

Zainol, M.K., Wong, K.Y., Mohd Zin, Z., Kamarudin, K.Z., Danish-daniel, A., Ng, K.S. and Mamat, H. (2018). Effect of ethanol in ultrasonic assisted extraction technique on antioxidative properties of passion fruit (Passiflora edulis) leaves. Malaysian Applied Biology Journal, 47(6), 19-27.

Zainol, M.K., Abd-Hamid, A., Yusof, S. and Muse, R. (2003). Antioxidative activity and total phenolic compounds of leaf, root and petiole of four accessions of Centella asiatica (L.) Urban. Food Chemistry, 81(4), 575-581. https://doi.org/10.1016/ S0308-8146(02)00498-3 